\title{
Delhi's Odd Plan Need Even Solutions
}

\author{
Subhash Aravapalli* \\ Department of finance and marketing, FBS Business School, Bangalore, India
}

*Corresponding Author: Subhash Aravapalli, Department of finance and marketing, FBS Business School, Bangalore, India

\begin{abstract}
This case study gives an overview of the critical condition of the air pollution in Newdelhi in 2015 as well 2017.it discusses the causes, major pollutants, effects and the government measures to control the air pollution levels. One of the government measures was the odd even formula, a plan to restrict private cars on the Delhi roads. This case also explains the details, strategies and regulations with respect to the formula and highlights the mixed reviews on its working of such incidents.
\end{abstract}

Keywords: Delhi air pollution, Odd even Formula, Measures to control pollution, Pollutants, Air quality (like effecting fogg, snow by city)

\section{Status of Air Pollution in Delhi}

Delhi is jointly administered by the central and state governments. It accommodates nearly 167.5 lakh people. Metros across the world bear the major brunt of environmental pollution; likewise, Delhi is at the receiving end in India. Vehicular pollution is an important contributor to air pollution in Delhi. According to the department of Delhi, vehicular population is estimated at more than 3.4 million, reaching here at a growth rate of $7 \%$ per annum. Although this segment contributes to two thirds of the air pollution, there has been a palpable decline compared to the 1995-1996 levels.

\section{Full CaSe}

Delhi's battle against air pollution started in 2001 when the Supreme Court expressed shock at the pollution levels in the city. It then ordered public buses, taxes and auto rickshaws to switch from diesel power to compressed natural gas. With the alarming level of air pollution in the city, the delhi high directed the central and state governments on December 32015 , to come up with a plan to control the pollution rate. The court directed the government to come up with measures list of measures by December 21 2015, to curb pollution. On December 4 2015, the Delhi government led by kejriwal proposed the 'ODD-EVEN PLAN' rule for private cars. The rule was proposed to be implemented from January 1 2016, as a pilot study for a period of 15 days. As per the rule, private vehicles would be allowed to play across the city based on their registration numbers. For example, if a vehicles registration number ended with an odd digit, it will be allowed on the road on January 2016, while a vehicle whose registration number ended with an even number would be allowed on January $2^{\text {nd }}$ and so on. The government thought that by implementing this rule and restricting number of the cars on the roads, the pollution levels could be brought down. Pollution in Delhi is out of control prompting a health emergency and to counter that, the state government has brought the oddeven rule back. The odd-even rule will be rolled out from November 13 to November 172017 in an attempt to reduce pollution in the nation's capital, all but a little too little too late. The odd even rule will mean that cars running with number plates ending even numbers like $0,2,4,6,8$ will be allowed to run on November 14 and November $16^{\text {th }}$ as well. on the other hand cars with number plates ending in odd numbers like 1,3,5,7,9 will be allowed to run on November 13,15 and November 17 . as with odd even rule before, certain cars? Vehicles and certain drivers will be exempt from the odd-even rule this time around too. On November $9^{\text {th }}$, the chief minister Arvin kejriwal - led government said as the odd-even road space rationing would be back on Delhi roads between November 13 - 17. A move aimed at clearing the smog that's indulged the capital city in thick-toxic embrace for a week. Exemptions, however, were going to be offered to women drivers, two wheelers and vehicles carrying children in school uniforms, apart from VVIPS, a move that irked the national green tribunal (NGT). 
On November $11^{\text {th }}$, however, the green tribunal allowed the Delhi government to go ahead with the plan while putting in place some riders - no one should be exempted from the scheme, except CNG vehicles and emergency services such as ambulance and fire, the NGT said.

It is also said that the schemes should be implemented "without any default" as and when particular matter 10 level goes above 500 micro grams per cubic meter and particular meter 2.5 level crosses the limit of 300 micrograms per cubic meter during a span of 48 hours.

The Delhi government, however, decided to call off the move, expressing its "inability to enforce the measure" as the number of buses that would fill in the absence of private vehicles were inadequate. Women's safety could not be compromised, the government said. The government also moved the NGT seeking amendment in its order on this scheme.

Most of time Delhi's air quality comes under "very poor" and "severe" condition.

\section{IT IS VERY EVIDENT FROM THE FIGURES THAT THE REDUCTION IN POLLUTION WAS NOT SO SIGNIFICANT.}

All the figures on an average almost remained the same. If you see what actually contributes to particularly matter 10 are

Road Dust $-56 \%$

Industrial source $-10 \%$

Concrete Batching $-10 \%$

Vehicles- $9 \%$

Others $-15 \%$

Although ODD-EVEN rule was applied on vehicles whose mere contribution is $9 \%$ and even in this there are many exemptions like two-wheeler and others. it was like handling a very small part of culprit . Now how can you expect a very big change?

Similar in this case with particulate matter vehicles contribution is $20 \%$ and other sources is $80 \%$

\section{THEN WHO IS DOING MAJOR POLLUTION APART FROM VEHICLES???}

CONCRETE BATCHING: there are nearly concrete batching plants working in Delhi for 16 hours per day.

- Restaurants: there are at least 10000 restaurants' which make tandoori roti's using tandoor. Each tandoor burns $\mathrm{kg} \mathrm{coal} /$ day.

- Burning of municipal solid waste

- Generators used during power cuts.

These are mere few but there are more other factors apart from vehicles which to be taken care. Sweeping roads four times in a month will bring road dust by $52 \%$. There are many other recommendations like this which the Delhi government has to implement.

\section{Vehicular Policy}

In Delhi, control measures so far instituted include introduction of unleaded petrol (1998), catalytic converter in passenger cars (1995) and reduction of sulphur content in diesel (2000). Other include construction of flyovers and subways for smooth traffic flow, introduction of metro rail and CNG for commercial transport vehicles (buses, taxis, rickshwas, auto), phasing out of very old commercial vehicles , introduction to of mandatory "pollution under control" certificate with 3 month validity and stringent enforcement of emission norms. Introduction of the air ambience fund levied from diesel sales and setting up of stringent emission norms for industries and thermal power stations are other measures. Environmental awareness campaigns are also carried out at regular intervals. The Delhi air pollution control board conducts monthly ambient air quality monitoring at 40 locations in Delhi and takes corrective action wherever necessary.

\section{OBJectives OF THE CASE}

- Know about air pollution in Delhi in 2015. 
- Understand the measures taken by government to control the air pollution levels in Delhi.

- Know about the ODD-EVEN formula and its impossible impact on working life of people in Delhi.

- Know how the other cities have adopted the odd even formula to regulate pollution.

\section{OUTCOMES OF THE CASE}

The odd-even rule has its impact when implemented for short duration, as people adopt alternatives if such rule is implemented for longer periods.

\subsection{For What it is, ODD-EVEN Rule has Certain Benefits}

- Reduces pollution? Better air quality - half of the cars, half of the pollution generated, especially for people suffering from respiratory conditions.

- Money saved - petrol/diesel less consumed saves both money for people and government also.

- Income to government - with no cars at disposal, one will have to travel by bus/metro/auto all of which provides revenue for government directly or indirectly.

- Reduced traffic- less time on road + more time on our hands, also emergency situations requiring transport can be handled better.

- Conversations-art of conversation or small talks helps a lot in life and car-pooling forces to done it up.

\subsection{For All its Benefit's, Following are Negatives}

- CNG sticker scam and such began in action, Corruption (traffic, police etc....)

- The autowallahs are able to harass more.

- One losses mobility of own car, Men cannot drive even for medical emergencies.

- Suffer boring talks/listen music of not your choice.

People coming to Delhi from outside are left without option, if your car and dates don't agree.

\section{CONClusion}

ODD-EVEN plan was not significantly successful. However, the effort made in controlling pollution by trying odd-even rule is really appreciable controlling pollution by trying odd-even rule is really appreciable.

\section{"BE A PART OF THE SOLUTION-}

\section{NOT PART OF THE POLLUTION"}

\section{REFERENCES}

[1] https://en.wikipedia.org/wiki/Odd\%E2\%80\%93even_rationing

[2] https://planningtank.com/dissertation/odd-even-rule-delhi-reason-merits-demerits

[3] https://www.quora.com/What-is-the-review-of-ODD-EVEN-rule-in-Delhi

[4] https://www.researchgate.net/publication/256481805_Air_pollution_in_Delhi_Its_Magnitude_and_Effects _on_Health

[5] https://www.timesnownews.com/mirror-now/in-focus/article/delhi-largest-contributor-vehicular-pollutionindia-cse-study-urban-commute/274756

Citation: Subhash Aravapalli. "Delhi's Odd Plan Need Even Solutions" International Journal of Managerial Studies and Research (IJMSR), vol 7, no. 1, 2019, pp. 19-21. doi: http://dx.doi.org/10.20431/ 2349. 0349.0701002 .

Copyright: (0) 2019 Authors. This is an open-access article distributed under the terms of the Creative Commons Attribution License, which permits unrestricted use, distribution, and reproduction in any medium, provided the original author and source are credited. 